\title{
Exchange Rate Volatility and Reserves Transparency
}

\author{
JOHN CADY and JESUS GONZALEZ-GARCIA*
}

The effects of the adoption of the IMF's International Reserves and Foreign Currency Liquidity Data Template on exchange rate volatility are investigated for 48 countries using panel data models and quarterly data from 1991 to 2005. In a model featuring significant relationships between nominal exchange rate volatility and fundamental macroeconomic variables, we find that the adoption of the reserves data dissemination standard is associated with a 20 percent decrease in volatility. Furthermore, adoption of the standard is also associated with changes in the relationships between exchange rate volatility and both indebtedness and reserve adequacy indicators. [JEL F31, F33, G14]

IMF Staff Papers (2007) 54, 741-754. doi:10.1057/palgrave.imfsp.9450025

he financial crises of the 1990s revealed a need for the dissemination of more comprehensive data on foreign currency liquidity positions to help prevent similar crises. In 1998, the IMF began working on initiatives in this area in collaboration with working groups of the Group of 10 (G-10) and the Group of 22 (G-22). The resulting International Reserves and Foreign Currency Liquidity Data Template (Reserves Template) became a prescribed element of the IMF's Special Data Dissemination Standard (SDDS). Data reporting under this initiative began in June 1999, and after a short transition period, SDDS subscribers were required to observe the standard as of April 2000.

The aims of introducing the Reserves Template extended beyond improving the frequency and timeliness of data dissemination on official

*John Cady and Jesus Gonzalez-Garcia are senior economists from the IMF's Statistics Department. The authors are grateful to William Alexander for suggesting this topic, and to IMF colleagues and an anonymous referee for their helpful comments and suggestions. 
reserve assets. Rather, the Reserves Template was intended to provide market participants with new data on foreign currency liabilities that, together with more complete information on foreign currency assets, would provide a more complete picture of national authorities' foreign currency liquidity positions. Under the new standard, detailed data dissemination is required on the following elements of the foreign currency liquidity position: official reserve assets, other foreign currency assets, and predetermined and contingent short-term inflows and outflows of foreign currency. In addition, subscribers are encouraged to report supplementary information that they deem relevant, including the currency composition of reserves (see Kester, 2001). Box 1 illustrates the type of new information disseminated via the Reserves Template, focusing on official releases by Canada and three other countries announcing their adoption of the new standard.

Both the SDDS initiative at a general level and the Reserves Template were aimed at increasing transparency and promoting the efficient functioning of markets. In particular, for the Reserves Template, the G-10 Working Group considered that greater transparency on foreign currency liquidity would help to remove a source of financial instability (see BIS, 1998, p. 1). The literature on the market efficiency benefits of standards and codes for data dissemination is relatively new, but empirical evidence indicating that emerging market subscribers to the SDDS face lower borrowing costs than nonsubscribers is accumulating (IIF, 2002; Christofides, Mulder, and Tiffin, 2003; Glennerster and Shin, 2003; Cady, 2005; and Cady and Pellechio, 2006). This paper focuses on foreign exchange markets and investigates whether the dissemination of Reserves Template data can be associated with changes in the volatility of nominal exchange rates. We hypothesize that increasing transparency and providing markets with more complete information about a country's foreign currency liquidity position could influence exchange rate volatility by permitting market participants to better assess a country's macroeconomic prospects, and in particular the implications of indebtedness and reserve adequacy.

Estimates of panel data models show intuitively appealing and statistically significant relationships between nominal exchange rate volatility and key macroeconomic variables. Building on these models and using policy evaluation techniques, we find that nominal exchange rate volatility decreases after dissemination of Reserves Template data, and the effects of indebtedness and reserve adequacy exhibit statistically significant changes. First, we find a reduction in the level of nominal exchange rate volatility following Reserves Template subscription, after controlling for country-specific macroeconomic developments and policies. Second, we find that the positive effect on volatility of higher debt/gross domestic product (GDP) ratios diminishes following Reserves Template data dissemination. Third, we find that the negative effect of reserves/short-term debt ratios on exchange rate volatility is reinforced following the adoption of the Reserves Template. These general findings are robust to differing estimation techniques and sample periods. 


\section{Box 1. Enhanced Disclosure Under the IMF's Reserves Template}

This box focuses on official announcements by Canada and three other countries regarding their adoption of the IMF's Reserves Template, and serves to illustrate the more complete information on foreign currency liquidity positions that is disseminated under the new standard. National publicity efforts reinforced those of the IMF itself; see the IMF's Public Information Notice No. 99/25 of March 26, 1999 (http://www.imf.org/external/np/sec/pn/ 1999/PN9925.HTM), which also includes a copy of the Reserves Template.

Countries generally make public announcements about their intentions to adopt the Reserves Template. These announcements are made through either the finance ministry or the central bank, as in the following examples:

Canada: http://www.fin.gc.ca/news99/data/99-038_1e.html

Sweden: http://www.riksbank.com/templates/News.aspx?id $=3975$

Turkey: http://www.tcmb.gov.tr/yeni/announce/ANO2002-24.html

Uruguay: http://www.bcu.gub.uy/autoriza/pepmaf/template/pepmafaniomesenglish.htm

The case of Canada is detailed here, drawing heavily from the official Department of Finance Canada press release of April 23, 1999, and a related background document.

On April 23, 1999, the minister of finance announced that the government of Canada planned to provide more information on its foreign currency liquidity position, beginning in July 1999. Up to that point, the key source of public information on international reserves had been the Department of Finance's monthly Official International Reserves press release, which provided key details on Canada's reserves position and explained major changes.

As a result of adopting the Reserves Template, the principal new data released by Canada consisted of:

1. Total reserves held in the form of foreign currency bank deposits disaggregated by three types of counterparties: other central banks and the Bank for International Settlements, banks headquartered in Canada, and banks headquartered outside Canada.

2. Total foreign exchange liabilities coming due within one year, disaggregated into three categories: due within one month, one to three months, and three to twelve months.

3. Total foreign currency forward positions against the Canadian dollar coming due within one year, disaggregated as in item 2 .

4. Total value of securities lent and held under repurchase agreements.

Previously, Canada released information on its stand-by facilities but, following IMF recommendations, this information was included in the Reserves Template as total net undrawn, unconditional credit lines in foreign currencies, broken down by three types of counterparties: other central banks, banks headquartered in Canada, and banks headquartered outside Canada.

Going beyond Reserve Template requirements, Canada also began releasing data on its key reserve assets on a weekly basis and net purchases of foreign currencies that had been transacted, but had not yet been settled. In addition, the line item for "Official Government Operations" of the official press release was disaggregated into three components: foreign currency debt charges, official government intervention, and net purchases of foreign currency to meet the budgetary requirements of government departments and Crown corporations and to replenish reserves. 


\section{Data and Estimation Methodology}

\section{Data}

The panel data set is comprised of quarterly time-series observations generally spanning the period 1991Q1 to 2005Q4, covering a broad crosssection of 48 countries, including industrial, emerging market, and lowincome countries. Among those countries, 39 are SDDS subscribers that initiated the dissemination of the Reserves Template at different dates after it was approved by the IMF in mid-1999. ${ }^{1}$ Eight countries serve as controls, as they neither subscribe to the SDDS nor disseminate Reserves Template data. ${ }^{2}$ Table 1 lists the countries considered, the dates of initial Reserves Template data dissemination, and the sample periods used for each country. In general, the data used for estimation cover approximately nine years before and six years after the introduction of the Reserves Template, but the data are unbalanced owing to differences in availability among countries.

\section{Modeling Exchange Rate Volatility}

Because we intend to apply tools from the policy evaluation literature to quarterly panel data, we need to calculate a quarterly measure of exchange rate volatility from relatively high-frequency data. The highest-frequency data available for real or effective exchange rate measures is monthly, and clearly this is inadequate to calculate standard deviations over the quarter. Over short horizons, nominal and real exchange rates are highly correlated, because nominal volatility is the main determinant of real exchange rate volatility. Furthermore, the first observable market efficiency effects of the dissemination of Reserves Template data would likely appear in foreign exchange markets, where transactions are made in nominal terms. Therefore, we focus on nominal exchange rate volatility, defined as the standard deviation of the first difference of the natural logarithm of daily bilateral exchange rates vis-à-vis the U.S. dollar, ${ }^{3}$ measured over the quarter.

Following the approach from the empirical policy evaluation literature (see Blundell and Costa Dias, 2000), the influence of Reserves Template data dissemination is examined using dummy variables, while controlling for country and period effects and a broad range of potential macroeconomic

\footnotetext{
${ }^{1}$ New Zealand, though not an SDDS subscriber, reports Reserves Template data that are redisseminated by the IMF.

${ }^{2}$ Eight control countries represent 20 percent of the subscribing countries in the sample. Clearly, in a controlled experiment or clinical trial, one would prefer a larger number of controls. However, this paper focuses on a natural experiment in which the pool of potential control countries is limited because many candidates have fixed exchange rate regimes over long periods and others were not considered because of insufficient time-series data. Crosssection variation is somewhat limited; therefore, identification of Reserves Template effects is expected to come mainly from the contrast of the before- and after-adoption periods.

${ }^{3}$ This measure is commonly used in the literature because it is unbiased by trends in the exchange rate series, since it tends to zero when the exchange rate closely follows a trend.
} 
Table 1. Dates of Initial Reserves Template Data Dissemination and Sample Periods

\begin{tabular}{|c|c|c|}
\hline Country & $\begin{array}{l}\text { Date of Initial Reserves Template } \\
\text { Data Dissemination }\end{array}$ & Sample Period \\
\hline 1. Argentina & March 22, 2000 & 1993Q2-2005Q3 \\
\hline 2. Australia & February 22, 2000 & 1991Q1-2005Q3 \\
\hline 3. Bolivia & Control, non-SDDS & 1994Q1-2004Q4 \\
\hline 4. Brazil & March 14, 2001 & 1994Q3-2005Q3 \\
\hline 5. Bulgaria & Control, non-SDDS & 1997Q3-2005Q3 \\
\hline 6. Canada & September 17, 1999 & 1991Q1-2005Q3 \\
\hline 7. Chile & June 1, 2000 & 1996Q2-2005Q3 \\
\hline 8. China & Control, non-SDDS & 1999Q3-2005Q3 \\
\hline 9. Colombia & June 12, 2000 & 1994Q2-2005Q3 \\
\hline 10. Croatia & May 31, 2000 & 1997Q2-2005Q3 \\
\hline 11. Czech Republic & April 10, 2000 & 1994Q1-2005Q3 \\
\hline 12. Denmark & June 23, 2000 & 1991Q1-2005Q3 \\
\hline 13. Estonia & April 1, 2000 & 1997Q2-2005Q3 \\
\hline 14. Hungary & July 2000 & 2000Q1-2005Q3 \\
\hline 15. Iceland & January 24, 2001 & 1997Q2-2005Q3 \\
\hline 16. India & December 2001 & 1997Q1-2005Q1 \\
\hline 17. Indonesia & July 7, 2000 & 1991Q1-2005Q3 \\
\hline 18. Israel & November 9, 2000 & 1991Q1-2005Q4 \\
\hline 19. Japan & June 9, 2000 & 1991Q1-2005Q3 \\
\hline 20. Jordan & Control, non-SDDS & 1994Q1-2004Q2 \\
\hline 21. Kazakhstan & March 24, 2003 & 1999Q3-2005Q2 \\
\hline 22. Korea, Rep. of & June 2000 & 1995Q1-2005Q2 \\
\hline 23. Latvia & June 14, 2000 & 1997Q2-2005Q3 \\
\hline 24. Lithuania & June 16, 2000 & 1997Q2-2005Q3 \\
\hline 25. Malaysia & May 31, 2000 & 1991Q2-2005Q3 \\
\hline 26. Mauritius & Control, non-SDDS & 1999Q2-2005Q1 \\
\hline 27. Mexico & April 17, 2000 & 1991Q1-2005Q3 \\
\hline 28. New Zealand & March 20, 2000, non-SDDS & 1991Q1-2005Q3 \\
\hline 29. Nigeria & Control, non-SDDS & 1994Q1-2003Q4 \\
\hline 30. Norway & June 9, 2000 & 1992Q1-2003Q4 \\
\hline 31. Paraguay & Control, non-SDDS & 1999Q2-2005Q1 \\
\hline 32. Peru & September 12, 2000 & 1994Q1-2005Q3 \\
\hline 33. Philippines & January 17, 2001 & 1991Q1-2005Q4 \\
\hline 34. Poland & May 31, 2000 & 1995Q2-2005Q3 \\
\hline 35. Russia & January 31,2005 & 1997Q1-2005Q3 \\
\hline 36. Singapore & June 21, 2000 & 1991Q1-2005Q4 \\
\hline 37. Slovak Republic & July 2000 & 1995Q1-2005Q3 \\
\hline 38. Slovenia & June 2000 & 1997Q2-2005Q3 \\
\hline 39. South Africa & May 31, 2000 & 1991Q1-2005Q3 \\
\hline 40. Sweden & April 2000 & $\begin{array}{c}\text { 1993Q2-2000Q4 } \\
\text { and } \\
\text { 2002Q1-2005Q4 }\end{array}$ \\
\hline 41. Switzerland & August 11, 1999 & 1991Q1-2005Q3 \\
\hline 42. Thailand & May 16, 2000 & 1993Q2-2005Q3 \\
\hline 43. Tunisia & December 4, 2000 & 2000Q2-2005Q3 \\
\hline 44. Turkey & June 9, 2000 & 1991Q1-2005Q3 \\
\hline 45. Ukraine & January 10, 2003 & 1998Q4-2005Q3 \\
\hline 46. Uruguay & February 12, 2004 & 1991Q1-2004Q4 \\
\hline
\end{tabular}




\section{Table 1 (concluded)}

Date of Initial Reserves Template

Data Dissemination Sample Period

\begin{tabular}{lll} 
Country & Data Dissemination & Sample Period \\
\hline $\begin{array}{l}\text { 47. United Kingdom } \\
\text { 48. Venezuela }\end{array}$ & September 17, 1999 & 1991Q1-2005Q3 \\
\hline
\end{tabular}

Source: IMF Dissemination Standards Bulletin Board (http://dsbb.imf.org/Applications/ web/dsbbhome/).

Note: A break in Swedish monetary data for 2001Q1-Q4 resulted in a small gap in the sample.

determinants of exchange rate volatility. We would have preferred using a generally accepted model of exchange rates; however, in this field there is no consensus in the literature. ${ }^{4}$ Thus, we have drawn on the empirical exchange rate volatility literature to select variables potentially affecting nominal exchange rate volatility (see Devereux and Lane, 2003; Hviding, Nowak, and Ricci, 2004; and Hausmann, Panizza, and Rigobon, 2006).

Nominal exchange rate volatility $(V O L E R)$ is hypothesized to be related to the following variables: indebtedness $(D G D P)$, measured as the government debt/GDP ratio; reserve adequacy $(R A)$, measured as the international reserves/short-term external debt ratio on a remaining maturity basis; the change in fiscal stance $(\triangle G B A L)$; real GDP growth $(\triangle G D P)$; inflation (INF); the volatility of money growth (VOLM); the current account balance/GDP ratio $(C A B)$; a measure of openness to trade of the economy $(O P E N)$; and dummy variables indicating periods of fixed exchange rates and periods of "managed" floating or intervention (FIX) and (INT), respectively. ${ }^{5}$ The basic estimating equation can be written as

$$
\begin{aligned}
\ln \left(\text { VOLER }_{i, t}\right)= & \beta_{0}+\beta_{1} \ln \left(D G D P_{i, t}\right)+\beta_{2} \ln \left(R A_{i, t}\right) \\
& +\beta_{3} \Delta G B A L_{i, t-2}+\beta_{4} \Delta G D P_{i, t}+\beta_{5} I N F_{i, t} \\
& +\beta_{6} \ln \left(\text { VOLM }_{i, t}\right)+\beta_{7} C A B_{i, t-3}+\beta_{8} \ln \left(O P E N_{i, t}\right) \\
& +\beta_{9} F I X_{i, t}+\beta_{10} I N T_{i, t}+u_{i, t} .
\end{aligned}
$$

This basic equation is used to construct a benchmark model in which the potential role of the Reserves Template will be tested. First, we tested for the absence of correlation between random effects, in both the cross-section and period dimensions, and the proposed set of macroeconomic variables. These

\footnotetext{
${ }^{4}$ See, for example, Sarno and Taylor (2002, Chapter 4).

${ }^{5} \mathrm{~A}$ detailed description of the variables used can be found in the appendix. Panel unit root tests indicate that all variables referred to in this paper can be considered stationary.
} 
tests indicated that consistent parameter estimates can be obtained using fixed cross-section and period effects. The residuals of the resulting model exhibited serial correlation, indicating the need to introduce an autoregressive term, AR(1). A likelihood ratio test rejected the hypothesis of a common autocorrelation coefficient for all countries; consequently, country-specific AR(1) terms are used throughout. Additionally, 29 countryspecific dummy variables for currency crises were introduced to eliminate outliers in the residuals, along with a time trend. In this estimated equation, the openness and current account variables were not statistically significant and were eliminated.

In the resulting equation (Table 2, column 2.1), the estimated coefficients of all macroeconomic variables have the expected signs. As one might expect, exchange rate fixing and episodes of managed floating or intervention tend to reduce volatility. Concerning macroeconomic fundamentals, increasing levels of reserve adequacy, real GDP growth, and improvements in the fiscal balance are associated with reduced exchange rate volatility. On the other hand, increases in volatility are correlated with higher indebtedness, inflation, and volatility of money growth. Despite being derived from an ad hoc model, these results are intuitively appealing and statistically significant. ${ }^{6}$ The latter aspect is likely a result of gains in efficiency owing to the use of a large panel data set (more than 2,000 observations) that allows the identification of correlations that have proven difficult to measure using single-country timeseries models.

To investigate the relationship between the dissemination of Reserves Template data and nominal exchange rate volatility, the benchmark model is modified as follows. A dummy variable $(R T)$ for each country subscribing to the Reserves Template takes the value of zero up to the quarter before initial dissemination and unity thereafter. This dummy is used to test for shifts in the level of volatility following adoption while controlling for the influence of all other variables. ${ }^{7}$ Additionally, interactive terms involving RT and indicators of indebtedness (DGDP) and reserve adequacy (RA) are used to test for changes in their estimated relationships with exchange rate volatility.

The estimation results are reported in Table 2, column 2.2. The coefficient estimate attached to the RT dummy variable is negative and statistically different from zero, indicating that dissemination of new information on foreign exchange liquidity positions data was associated with a downward shift in the level of nominal exchange rate volatility. The estimated coefficient indicates a decline in volatility of 20 percent following

\footnotetext{
${ }^{6}$ Using White robust standard errors for panel data models does not alter any conclusions about the statistical significance of parameter estimates.

${ }^{7}$ The adoption of the Reserves Template was an addition to the requirements of the existing SDDS; therefore, its adoption by countries is considered an exogenous event. This is the case for the majority of countries considered; only five countries in the sample subscribed to the SDDS after the Reserves Template became a requirement.
} 
dissemination of the Reserves Template, after controlling for all other variables considered in the model and country and time effects. ${ }^{8}$

The positive coefficient estimate attached to the indicator of indebtedness implies that highly indebted countries tend to have more volatile nominal exchange rates. However, the coefficient estimate attached to the indebtedness-RT interaction term is negative and statistically different from zero, suggesting that following adoption of the new standard, external debt/GDP ratios are associated with a diminished, yet still positive, effect on nominal exchange rate volatility.

The estimates indicate a statistically significant negative relationship between nominal exchange rate volatility and reserve adequacy, suggesting that currencies of countries with higher reserves/short-term debt ratios tend to be less susceptible to large exchange rate variations. Concerning the interaction of RT with reserve adequacy, the estimated coefficient is negative and statistically significant, indicating that the level of reserve adequacy has an enhanced dampening effect on nominal exchange rate volatility for subscribing countries.

These results are not dependent on a specific sample period. The stability of the coefficient estimates over time, particularly those involving the RT dummy variable, has been examined using recursive estimation. Regressions with sample periods starting with 1991-2000 and ending with 1991-2005 found that the coefficient estimates attached to the RT dummy variable and its interaction terms are quite stable (Figure 1).

To investigate whether adoption of the Reserves Template has different implications for different types of economies, the model was estimated separately using data for 12 industrial countries and for 16 emerging market countries that had experienced episodes of exchange market pressure during the sample period. ${ }^{9}$

In the case of industrial countries (Table 2, column 2.3), all variables included in the benchmark model are significant and have the expected signs, with the exception of indebtedness. Reserve adequacy has a statistically significant negative effect on volatility, which is enhanced following Reserves Template dissemination, and there is a statistically significant downward shift in the level of exchange rate volatility, while indebtedness remains statistically insignificant. For industrial countries, it would seem that solvency considerations do not play a role in exchange rate volatility, but that volatility is influenced by a broad range of macroeconomic variables and the information content of the Reserves Template.

\footnotetext{
${ }^{8} \mathrm{We}$ are grateful to an anonymous referee for noting that using period effects would prevent confusing the effects of dissemination of new information with those possibly resulting from benign international liquidity conditions, as well as events and reforms with global effects, the impacts of which are captured by quarter-specific period, or time, effects.

${ }^{9}$ The episodes of exchange market pressure were identified by Ramakrishnan and Zalduendo (2006).
} 
Figure 1. Recursive Coefficient Estimates
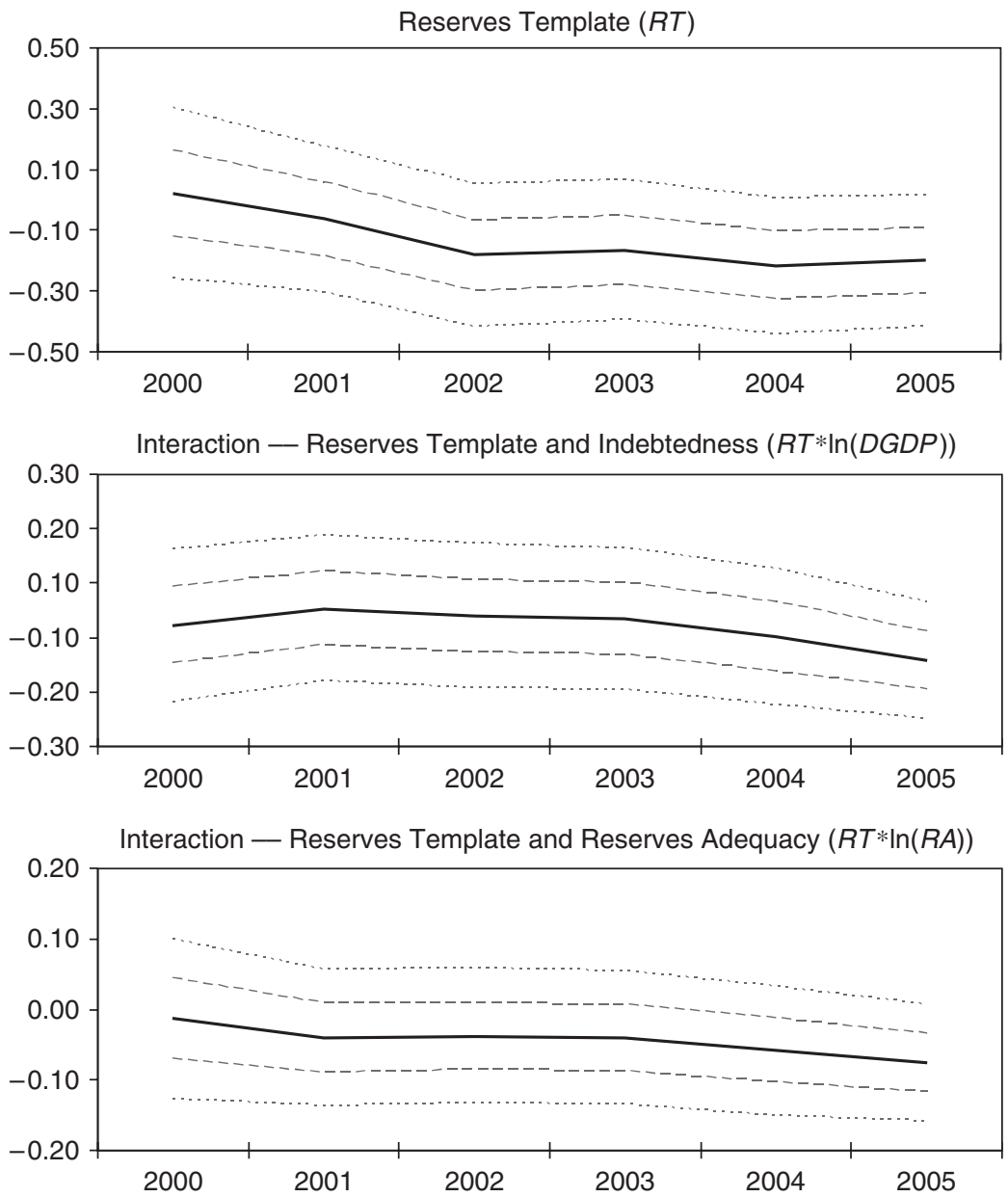

Source: Author's calculations.

Note: Dashed and dotted lines indicate one and two standard error bands.

The adoption of the Reserves Template also plays a role when a group of 16 emerging market countries is considered (Table 2, column 2.4). In this case, both indebtedness and reserve adequacy considerations are associated with exchange rate volatility in the benchmark portion of the model, but only the solvency relationship appears affected by Reserves Template dissemination, as the positive effect of increasing indebtedness on volatility is reduced after adoption of the standard. In addition, the downward shift in the constant term associated with RT is statistically significant and somewhat larger than that estimated for the 12 industrial countries. Concerning other macroeconomic variables, only GDP growth, inflation, and fixed exchange rate regimes show statistically significant relationships with volatility. 


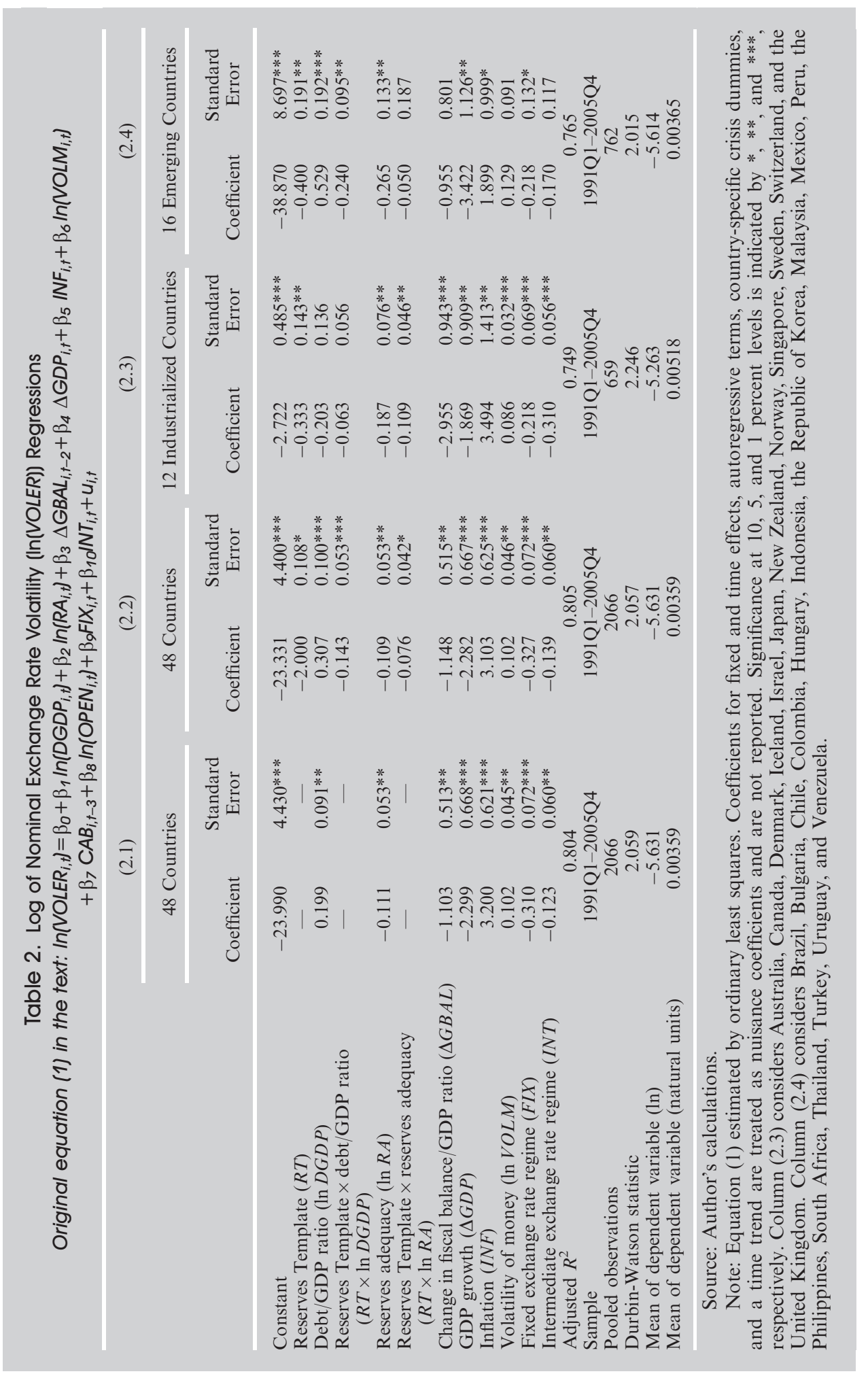


It bears mentioning that for both groups of countries, we find a downward shift in the level of nominal exchange rate volatility following Reserves Template adoption-yet there are interesting differences regarding the interactive terms. Although the degree of indebtedness may not be a relevant issue in the case of the industrial countries considered, improved reserve adequacy does tend to reduce the volatility of nominal exchange rates, and this relationship becomes stronger after a country adopts the Reserves Template. In contrast, for emerging market countries, increasing indebtedness is associated with higher exchange rate volatility, but this effect is diminished following the dissemination of Reserves Template data. On the other hand, reserve adequacy has a significant relationship with volatility, but Reserves Template adoption does not seem to have altered it.

To explore the possibility that the effects captured by the Reserves Template dummy and the associated interactive terms are related to subscription to the SDDS instead of the dissemination of Reserves Template data, we estimated two versions of the model in which a dummy variable and interactive terms associated with SDDS subscription for each country were included. First, we allowed for a general SDDS effect on volatility by including an SDDS variable for each country in addition to the Reserves Template dummy variable and associated interactive terms. In this estimation, the coefficient estimate attached to the SDDS dummy variable was very small and statistically insignificant, whereas the $R T$ dummy and interactive terms retained their size, sign, and significance. Second, the $R T$ dummy variable and interactions were replaced with similar variables representing SDDS subscription dates. None of the estimated coefficients attached to these SDDS variables were statistically significant. Taken together, these tests show that SDDS had no particular effects on nominal exchange rate volatility, and therefore, we could not be incorrectly attributing such SDDS effects to the dissemination of Reserves Template data.

All of our estimations were performed using ordinary least squares (OLS), but endogeneity, or correlation of an explanatory variable with the error term, is a potential issue. We have investigated the effects of potentially endogenous regressors by estimating model 2.2 of Table 2 with instrumental variables. In a first alternative, we treated as potentially endogenous regressors the debt/GDP and reserve adequacy ratios, as well as the RT dummy variable and its associated interaction terms, using lagged values as instruments. In a second alternative, all explanatory variables are treated as potentially endogenous, and were instrumented using lagged values. ${ }^{10}$ In both cases, the results and conclusions are similar to the OLS estimates and can be interpreted as diminishing the importance of potentially endogenous regressors as a practical issue.

\footnotetext{
${ }^{10}$ The fiscal stance was not instrumented because it enters the estimating equation with lags.
} 


\section{Conclusion}

Using a large panel data set involving 48 countries, statistically significant relationships between nominal exchange rate volatility and a set of macroeconomic variables were identified, then the effects of Reserves Template data dissemination were investigated. Our estimated benchmark model found intuitively appealing and statistically significant relationships between nominal exchange rate volatility and key macroeconomic variables.

Combining the benchmark model with techniques from policy evaluation literature, robust results indicate that providing markets with additional information about foreign currency liquidity positions has reduced nominal exchange rate volatility by allowing market participants to better assess the implications of a country's macroeconomic situation, in particular concerning indebtedness and reserve adequacy. More specific results suggest that for industrial countries, the diminishing effect of reserve adequacy on nominal exchange rate volatility is enhanced following Reserves Template data dissemination; whereas for emerging market countries, the positive influence of indebtedness on volatility is reduced.

\section{APPENDIX}

VOLER: The quarterly standard deviation of the first difference of the natural logarithm of daily bilateral exchange rates (domestic currency units per U.S. dollar). Source: Datastream.

$R T$ : Dummy variable indicating adoption of the Reserves Template. Dates for initial dissemination of Reserves Template data were determined from IMF records.

DGDP: Government debt/GDP. Data on debt stocks were taken from the IMF's World Economic Outlook (WEO) database and for GDP from IMF's International Financial Statistics (IFS) database. Annual debt stocks were used as quarterly estimates by repeating the annual figure each quarter.

$R A$ : Ratio of international reserves/short-term external debt outstanding on a remaining maturity basis, in the case of the 36 low-income and emerging market countries. For industrial countries, the debt stocks used refer to total general government debt. Quarterly data on international reserves were drawn from the IFS. Annual debt stocks, taken from the WEO, were used as quarterly estimates by repeating the annual figure each quarter.

$\triangle G B A L$ : Change in general government balance/GDP ratio. General government balances were drawn from the WEO. Annual figures were used to represent quarterly values using the same value every quarter divided by quarterly nominal GDP drawn also from IFS.

$\triangle G D P$ : GDP growth rates, measured on a purchasing power parity basis, expressed in U.S. dollars. GDP series were drawn from the WEO database and deflated using the U.S. GDP deflator. Again, annual figures are used to represent quarterly values. 
$I N F$ : Annual rate of growth of consumer price indices, taken from IFS.

VOLM: Standard deviation of month-to-month broad money growth rates for the 12-month period ending each quarter. Monthly monetary data were obtained from IFS.

$C A B$ : Current account balance/GDP ratio. Quarterly data on current account balances and GDP were drawn from the IFS.

OPEN: Openness is the sum of exports and imports of goods and services divided by GDP, both measured in U.S. dollars. Both items were drawn from the IFS.

FIX and INT: Dummy variables indicating periods of fixed exchange rates or dirty floating, respectively; periods of floating serve as the benchmark category. Both variables were constructed using the Levy-Yeyati and Sturzenegger (2005) de facto three-way classification.

\section{REFERENCES}

Bank for International Settlements (BIS), 1998, "Enhancing Transparency Regarding the Authorities' Foreign Currency Liquidity Position," Report of a Working Group Established by the Euro-Currency Standing Committee of the Central Banks of the Group of Ten Countries (Basel, September 28). Available via the Internet: http:// www.bis.org/publ/ecsc09.pdf.

Blundell, Richard, and Monica Costa Dias, 2000, "Evaluation Methods for NonExperimental Data," Fiscal Studies, Vol. 21 (January), pp. 427-68.

Cady, John, 2005, "Does SDDS Subscription Reduce Borrowing Costs for Emerging Market Economies? IMF Staff Papers, Vol. 52 (December), pp. 503-17.

— and Anthony Pellechio, 2006, "Sovereign Borrowing Cost and the IMF's Data Standards Initiatives," IMF Working Paper 06/78 (Washington, International Monetary Fund).

Christofides, Charalambos, Christian Mulder, and Andrew Tiffin, 2003, "The Link Between Adherence to International Standards of Good Practice, Foreign Exchange Spreads, and Ratings," IMF Working Paper 03/74 (Washington, International Monetary Fund).

Devereux, Michael, and Philip Lane, 2003, "Understanding Bilateral Exchange Rate Volatility,” Journal of International Economics, Vol. 60 (May), pp. 109-32.

Glennerster, Rachel, and Yongseok Shin, 2003, "Is Transparency Good for You, and Can the IMF Help?," IMF Working Paper 03/132 (Washington, International Monetary Fund).

Hausmann, Ricardo, Ugo Panizza, and Roberto Rigobon, 2006, "The Long-Run Volatility Puzzle of the Real Exchange Rate," Journal of International Money and Finance, Vol. 25 (February), pp. 93-124.

Hviding, Ketil, Michael Nowak, and Luca Antonio Ricci, 2004, "Can Higher Reserves Help Reduce Exchange Rate Volatility?” IMF Working Paper 04/189 (Washington, International Monetary Fund).

Institute of International Finance (IIF), 2002, IIF Action Plan Proposals and Dialogue with the Private Sector, Appendix D, "Does Subscription to the IMF's Special Data Dissemination Standard Lower a Country's Credit Spread?” (Washington, IIF). 
Kester, Anne Y., 2001, International Reserves and Foreign Currency Liquidity: Guidelines for a Data Template (Washington, International Monetary Fund).

Levy-Yeyati, Eduardo, and Federico Sturzenegger, 2005, "Classifying Exchange Rate Regimes: Deeds vs. Words," European Economic Review, Vol. 49 (August), pp. 1603-35.

Ramakrishnan, Uma, and Juan Zalduendo, 2006, "The Role of IMF Support in Crisis Prevention," IMF Working Paper 06/75 (Washington, International Monetary Fund).

Sarno, Lucio, and Mark P. Taylor, 2002, The Economics of Exchange Rates (Cambridge, United Kingdom, Cambridge University Press). 